\title{
GROWTH ASSESSMENT OF EXOTIC SUGAR BEET VARIETIES IN SOUTHERN-ZONE OF SINDH
}

\author{
Ghulam Muhiyuddin Kaloi*, Ali Hassan Mari*, Naimatullah Bughio*, Salahuddin Junejo*, Riaz Noor \\ Panhwar*, M. Abbas Bhutto**, M. Aslam Rajput*, Samia Arain* \\ *National Sugar and Tropical Horticulture Research Institute, PARC, Thatta, \\ ${ }^{* *}$ Food Quality \& Safety Research Institute, SARC, Karachi
}

\section{ABSTRACT}

Ten hybrid exotic sugar beet varieties were tested under four locations in southern-zone of Sindh during 2009-10. Experiments was in a randomized complete block design (RCBD), replicated thrice. Seeds were planted on top of the ridges by using 2-3 seeds per hole. Plant to plant and row to row space was maintained at 20 and $100 \mathrm{~cm}$, respectively. Nitrogen $\left(120 \mathrm{~kg} \mathrm{ha}^{-1}\right)$ and phosphorus (100 kg ha-1) applied in the form of Urea and DAP, while the potassium was excluded completely. The values of physico-chemical properties of experimental soils were in a wide range. The soils were slightly alkaline in nature $(\mathrm{pH} 7.68-8.46)$ with 1.66-8.78 dSm${ }^{-1} \mathrm{EC}, 3.62-7.84 \mathrm{ppm}$ available phosphorus, 128-364 ppm available potassium, 5.50-60.54 meq L-1 exchangeable sodium, 11-51.4 meq L-1 soluble calcium + magnesium. The textural class was clay-clay loam. The germination (74\%) was higher at location Hussainy Agricultural Farm Matiari. The yield was higher at NSTHRI Thatta, Ramesh Agricultural Farm Sujawal and Hussainy Agricultural Farm Matiari, all were statistically at par $\left(60.41\right.$ to $\left.62.57 \mathrm{t} \mathrm{ha}^{-1}\right)$. The sugar recovery was higher (14.44 $\%)$ at RAF Sujawal. Among varieties, the germination percent was statistically at par for all varieties (67.26-70.75 \%) except the Esteban and California (66.25-66.76 \%). The higher sugar beet yield (64.03 t ha-1) was noted in SD-12970, however the varieties Sandrina, SD-PAK 07/07 and SD-PAK 09/07 were statistical at par with the variety SD-12970. Maximum sugar recovery of $13.88 \%$ was noted in SD-PAK 07/07. The varieties Antek, SD-PAK 04/06 and SD-PAK 09/07 were statistically likewise with SD-PAK 07/07. The growth performance of Antek, California, SD12970, SD-PAK 09/07 and SD-PAK 07/07 found better under climatic condition of southern-zone of Sinsh

Key words: Sugar beet varieties, beet yield, sugar recovery, climate, Southern-zone, Sindh

\section{INTRODUCTION}

Sugar beet is considered to be temperate crop but some varieties have performed best in climatic conditions of subtropics. It can be grown successfully as a winter crop in subtropical regions (Kapur and Kanwar, 1990). In Pakistan, sugar beet has remained in commercial cultivation for the last more than four decades especially in Khyber Pakhtunkhwa (KPK). During 2010-11 cropping season, 151,286 tons of sugar beet was sliced producing around 13,535 tons of sugar with and average sugar recovery recorded was $8.95 \%$ (Annual Report PSMA-SZ, 2011). It is well known for salinity tolerance. But, the drought stress causes profit loss to the sugar beet crop (Abu et al., 2010). However, it could be efficiently grown under a wide range of irrigation level. The crop has better adaption quality even in limited irrigation because plants utilize deep stored soil water and recover quickly following drought stress (Monreal et al., 2006). The climatic conditions of southern-zone of Sindh are similar to the Nile delta valley in Egypt which is a promising area for sugar beet production since many years 
(Wandke et al., 2007). Due to no frost and mild winter temperatures, southern-zone of Sindh is a favorable area for sugar beet cultivation. In Sindh province, this crop has recently been tested for growth performance at different research institutes under varied agro-climatic conditions. The soil and climatic conditions for sugar beet cultivation have been proved favorable particularly in south Sindh (Memon et al., 2004). Similarly, the other researchers reported better performance of different exotic sugar beet varieties under agro-climatic conditions of Sindh (Tunio et al., 2004 and Oad et al., 2007).

Consequently, Government of Pakistan through Pakistan Agricultural Research Council (PARC) an apex body in national agricultural research system has taken initiatives to introduce sugar beet as an alternate sugar crop in the country. With this respect, government imported seeds of some exotic sugar beet varieties. The seeds were supplied to various research establishments including National Sugar and Tropical Horticulture Research Institute (NSTHRI), PARC, Thatta for assessment of their adaptability in southern-zone of Sindh. Keeping the above facts in view, this study was conducted to evaluate the performance of exotic sugar beet hybrid varieties under agro-climatic conditions of southern-zone of Sindh.

\section{MATERIALS AND METHODS}

Ten exotic hybrid sugar beet varieties were investigated on four locations to assess the performance under agroclimatic conditions of southern-zone of Sindh during 2009-10. The sugar beet varieties; Antek, California, Ernestina, Esteban, Sandrina, SD12970, SD-PAK 03/06, SDPAK 04/06, SD-PAK 07/07 and SDPAK 09/07 were grown at National Sugar and Tropical Horticulture Research Institute (NSTHRI) district Thatta; Ramesh Agricultural Farm (RAF) district Sujawal; Noor Ahmed Agricultural Farm (NAF) district Badin, and Hussainy Agricultural Farm (HAF) district Matiari. Prior to planting, composite soil samples from each location were collected and analyzed to determine selected soil physic-chemical properties (Table 1).

The experiments were designed following randomized complete block design (RCBD) with three replications. In all the trial plots each sugar beet variety was planted on 8 meters long 4 ridges (plot size $32 \mathrm{~m}^{2}$ ). The seeds were sown on the top of the ridges, by using 2-3 seeds per pit and plant to plant and row to row space at $20 \mathrm{~cm}$ and $100 \mathrm{~cm}$, respectively was maintained. The fertilizer dozes @ 120, $100 \mathrm{~kg}$ nitrogen and phosphorus per hectare in the form of Urea and DAP was applied. All the DAP and $1 / 3$ urea was applied in furrows at the time of planting, remaining dose of urea was applied in two split dozes. The recommended irrigations applied to sugar beet at each location varied and scheduled according to availability of water at the area. The locations NSTHRI Thatta, RAF Sujawal, NAF Badin and HAF Matiari received 8, 6, 4 and 8 irrigations, respectively.

The agronomic practices, insect pest and disease control measures were taken as and when required throughout the growing season. The data regarding assessment of growth parameters were analyzed statistically using two way analysis of variance (ANOVA) and all means were separated by least significant difference (LSD) using software program Statistix 8.1 (Analytical Software, 2005).

\section{RESULTS}

Growth of exotic sugar beet genotypes were investigated on four different locations of southern-zone of Sindh for growth assessment like germination, beet weight, number of beets per hectare, beet yield and sugar recovery percent. Statistical analysis indicated that the effect of location, variety and interaction of the both (location $\times$ variety) was significant $\quad(P<0.05) \quad$ with 
regard to growth parameters except in case of number of beets per hectare. However the interaction (location $x$ variety) was significant for number of beets.

\section{Germination percent}

Sugar beet germination percentage presented in Figure 1 revealed that germination was significantly higher at HAF Matiari (74.80 $\%)$ and RAF Sujawal (71\%) followed by NSTHRI Thatta and NAF Badin, which were remained at par with 64.30 and $63.90 \%$, respectively. Varieties like SD-12970, Antek and SD-PAK 09/07 were found best over other varieties with $70.75,69.75$ and $69.50 \%$ germination, respectively. Among locationvariety interaction, highest significant germination (78\%) was found under SD-PAK 07/07 at HAF Matiari and minimum (59 \%) for Esteban at NAF Badin.

\section{Beet weight}

Beet weight (Figure 2) showed that beet weight at RAF Sujawal and HAF Matiari were at par with $1.31 \mathrm{~kg}$ per beet, followed by NSTHRI Thatta $(1.30 \mathrm{~kg})$ while, minimum $(0.81 \mathrm{~kg})$ was observed at NAF Badin location. Whereas, within varieties, SD-12970, SD-PAK 09/07 and Sandrina with beet weight of $1.35,1.29$ and 1.27 $\mathrm{kg}$ respectively, were best over other varieties. Among location-variety interaction, significantly highest beet weight $(1.55 \mathrm{~kg})$ was observed under SD-12970 at NSTHRI Thatta and minimum $(0.61 \mathrm{~kg})$ for SD-PAK 04/06 at NAF Badin location.

\section{Number of beets per hectare}

Data with respect to number of beets shown in Figure 3 revealed that maximum beet counts were obtained under locations of RAF Sujawal and HAF Matiari and were remained at par with 47.85 , 47.44 thousand beets per hectare. The NSTHRI Thatta and NAF Badin produced 46.48 and 44.85 thousand beets per hectare, respectively. While, within varieties SD-PAK 09/07, SD12970 and SD-PAK 07/07 with 48.56, 47.83 and 47.49 thousand beets, respectively, were best over remaining varieties. Among locationvariety interaction, maximum on par (50.00 thousand) number of beets were counted in varieties SD12970 and SD-PAK 09/07 at RAF Sujawal and Sandrina and SD-PAK 07/07 at HAF Matiari, while, minimum (36.65. thousand) beets were found under Esteban at NAF Badin.

\section{Beet yield}

Data regarding beet yield presented in Figure 4, showed that HAF Matyari, RAF Sujawal and NSTHRI Thatta observed best locations with $62.57,62.38$ and $60.41 \mathrm{t} \mathrm{ha}^{-1}$ respectively. While, location of NAF Badin was poor with $36.34 \mathrm{t} \mathrm{ha}^{-1}$ yield. Among varieties, SD-
12970, SD-PAK 09/07 and Sandrina with $64.03,62.53$ and $60.63 \mathrm{t} \mathrm{ha}^{-1}$ respectively were found best with respect to beet yield over Esteban (46.17 t ha-1), Antek (53.05 t $\mathrm{ha}^{-1}$ ) and SD-PAK 04/06 $\left(45.60 \mathrm{t} \quad \mathrm{ha}^{-1}\right)$. Among location-variety interaction; maximum beet yield $(76.65 \mathrm{t}$ $\mathrm{ha}^{-1}$ ) was found under SD12970 at RAF Sujawal and minimum for (26.39 $\left.\mathrm{t} \mathrm{ha} \mathrm{ha}^{-1}\right)$ Esteban at NAF Badin.

\section{Sugar recovery}

Sugar recovery data (Figure 5) indicated, where, significantly higher (14.44\%) sugar recovery was observed under RAF Sujawal, while, minimum (9.92 \%) sugar recovery observed under NAF Badin. Among varieties, SD-PAK 07/07, SD-PAK 09/07 and Antek with 13.88, 13.58 and $13.52 \%$ sugar recovery were significantly best over SD-12970 (12.17 $\%)$, SD-PAK 03/06 (12.12\%) and Sandrina (11.59 \%). Among location-variety interaction, maximum sugar recovery $(15.75 \%)$ was found for Esteban at RAF Sujawal and minimum $(8.18 \%)$ for same variety Esteban at NAF Badin.

\section{DISCUSSION}

The study was carried out to check the growth performance of some exotic sugar beet varieties under agro-climatic conditions of Sindh. The results indicated that performance regarding 
germination, sugar beet yield and sugar recovery was highly significant. Such positive response truly indicated the environmental suitability and adoptive capability of sugar beet in the area. However, the change in growth performance between the locations might be due to climatic factors (light, temperature and day length) and site-specific biophysical factors $(\mathrm{pH}, \quad$ electrical conductivity, exchangeable sodium, status of soil nutrient and irrigation water) and variety potential as well.

The agro-climatic factors have important role in yield and recovery of sugar beet. It accounted for over $26-80 \%$ of yield variability (Hoffmann et al., 2009 and Marlander et al., 20l3). According to Ebrahimian et al. (2009), there was a significant change in growth performance of sugar beet varieties tested under different locations of Iran. The sugar beet varieties tested on different locations in southern zone of Sindh showed significant variation in growth performance (germination, beet yield and sugar recovery).

The maximum average germination was noted at location of HAF Matiari was higher by 5, 14 and $15 \%$ over RAF Sujawal, NSTHRI Thatta and NAF Badin locations, respectively. RAF Sujawal and HAF Matiari gave at par average number beets, closely followed by NSTHRI Thatta. Similarly, the average sugar beet yield was higher at HAF Matiari, closely followed by RAF Sujawal location. As for sugar recovery, the location RAF Sujawal was significantly higher by 8,10 and $31 \%$ over the locations of NSTHRI Thatta, HAF Matiari and NAF Badin, respectively. The climatic and biophysical factors of all locations significantly favored the growth of sugar beet. In case of NAF Badin location, where unsatisfactory performance of suagbeet was seen. It might be due to low irrigation water. The location received only 4 irrigations as compared other locations (6-8 irrigation).

Minimum 6 irrigations were needed to get economical yield. The sugar beet is considered to low delta crop but its growth is significantly affected in drought conditions. Richter et al. (2001) reported that drought stress was the major cause of low beet yield. Jaggard et al. (1998) reported $10 \%$ decrease in sugar beet yield in stress conditions, while it reached up to $50 \%$ in dry period. Similarly, water stress caused a serious reduction in sugar beet yield and recovery as stated by Pidgeon et al. (2001). As for varietal performance, 2-7 \% variation was found in germination, 30 $50 \%$ in beet weight, 2-29\% in sugar beet yield and 2-16 $\%$ in sugar recovery in intra locations. The number of beets per hectare was nonsignificant.

The higher germination and sugar beet yield was found in SD-12970. The SD-12970 surpassed to the variety Esteban by $6.36 \%$, California $5.72 \%$ and Ernestina $4.95 \%$ with regard to germination. Similarly, SD-12970 surpassed SD-PAK 04/06 by $29 \%$, Antek by $17 \%$ and Ernestina by $16 \%$ with regard to sugar beet yield. Whereas, maximum sugar recovery was noted in SDPAK 07/07. The sugar recovery was higher by 17 , 15 and $13 \%$ over the Sandrina, Ernestina and SDPAK 03/06 varieties, respectively. The outcomes of experiment were found satisfactory with reference to germination, sugar beet yield and sugar recovery. The results are in accordance with Kaloi et al. (2014), Khan et al. (2004) and Oad et al. (2001), who reported likewise results.

\section{ECONOMIC ANALYSIS}

Economic analysis (Table 2) indicated that maximum income of Rs. $116221 \mathrm{ha}^{-1}$ was obtained in variety SD12970, followed by SD PAK 09/07 (Rs. 112659 ha $^{-1}$ ) as compared to income of sugarcane (Rs. 137550 ha $^{-1}$ ). The income was higher by only Rs. 21329 ha $^{-1}$ against SD PAK -12970 and Rs. 24891 ha $^{-1}$ against SD PAK 09/07. The mean values indicated an increase of Rs. 41775 ha $^{-1}$ over sugar beet. It is mentionable that sugar 
beet is a 5-6 month crop needs only 6-8 irrigations as compared to sugarcane which is a long duration crop (12-14 months) needs 25-33 irrigations. Henceforth, the net increment of Rs. 41775 might be very expensive on the cost of time and quantity of irrigation water.

\section{CONCLUSION}

Overall, the southern-zone of Sindh Pakistan was found better for cultivation of sugar beet. The cultivation of sugar beet may be a partial replacement of the high delta sugarcane crop. It will increase also the crashing period of Sugar Mills for period of 2-3 months (MarchMay). The varieties SD-PAK 09/07, SD-12970, SD-PAK 07/07, Antek and California were found best with regard to yield and recovery. Hence, these varieties may be cultivated on commercial basis in southern-zone of Sindh.
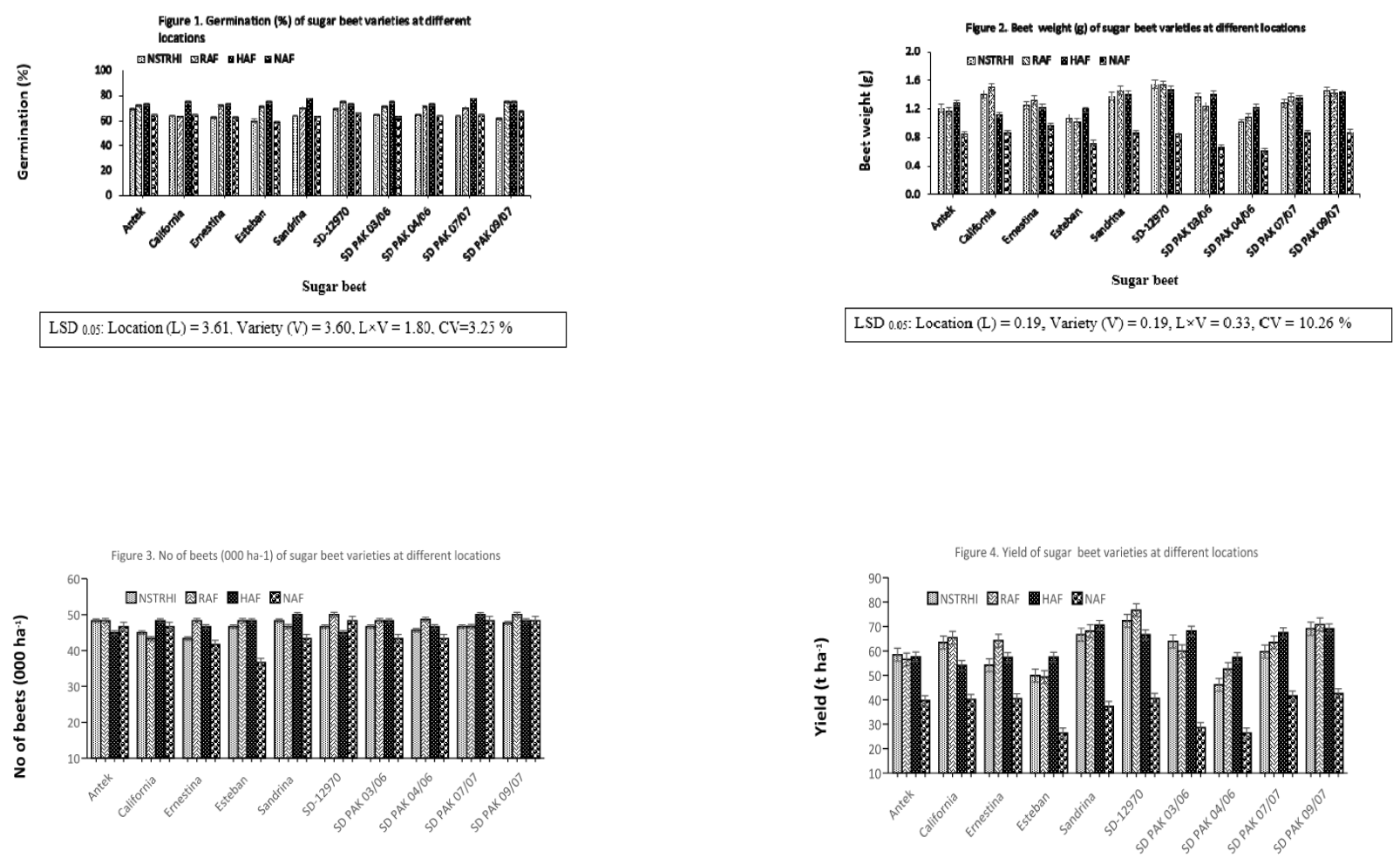

$\operatorname{LSD}_{0.05}$ : Location $(\mathrm{L})=\mathrm{NS}$, Variety $(\mathrm{V})=\mathrm{NS}, \mathrm{L} \times \mathrm{V}=1.70, \mathrm{CV}=4.50 \%$

Sugar beet varieties

$\operatorname{LSD}_{k, 3: 3:}$ Location $(\mathrm{L})=6.22, \operatorname{Variety}(\mathrm{V})=6.22, \mathrm{~L} \times \mathrm{V}=3.11, \mathrm{CV}=6.91 \%$ 


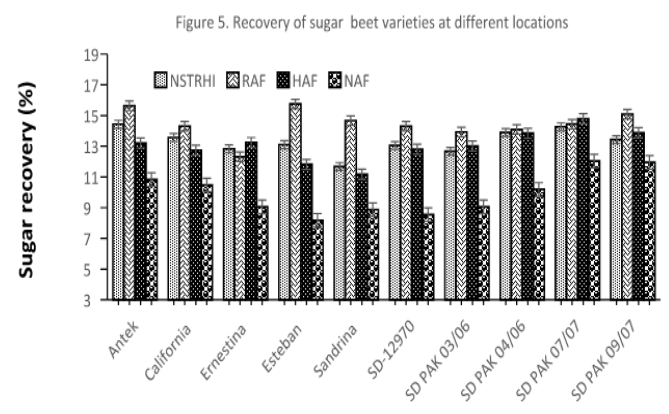

Sugar beet varieties

$\mathrm{LSD}_{0.05}:$ Location $(\mathrm{L})=1.10$, Variety $(\mathrm{V})=1.10, \mathrm{~L} \times \mathrm{V}=0.55, \mathrm{CV}=5.36 \%$

Table-1 Physico-chemical properties of experimental soils during 2009-10

\begin{tabular}{|c|c|c|c|c|c|c|c|}
\hline Location & Texture & pH & $\begin{array}{c}\mathrm{EC} \\
\left(\mathrm{dS} \mathrm{m}^{-1}\right)\end{array}$ & $\begin{array}{c}\text { Available P } \\
\text { (ppm) }\end{array}$ & $\begin{array}{l}\text { Available K } \\
\text { (ppm) }\end{array}$ & $\begin{array}{l}\text { Sol \& Ex. Na } \\
\quad\left(\mathrm{meq} \mathrm{L} \mathbf{L}^{-1}\right)\end{array}$ & $\begin{array}{l}\text { Soluble Ca + } \\
\operatorname{Mg}\left(\operatorname{meq} L^{-1}\right)\end{array}$ \\
\hline NSTHRI Thatta & Clayey & 7.88 & 8.78 & 4.49 & 364 & 60.54 & 51.40 \\
\hline RAF Sujawal & Clayey & 7.68 & 3.86 & 3.62 & 180 & 16.54 & 24.00 \\
\hline HAF Matiari & Clay loam & 8.46 & 1.66 & 7.84 & 128 & 5.50 & 17.60 \\
\hline NAF Badin & Clay loam & 8.10 & 1.92 & 3.62 & 156 & 12.86 & 11.60 \\
\hline
\end{tabular}

Table-2 Economic analysis of sugar beet and sugarcane

\begin{tabular}{|c|c|c|c|c|c|c|c|c|c|c|c|}
\hline \multirow{2}{*}{$\begin{array}{c}\text { Sugar beet } \\
\text { variety }\end{array}$} & \multicolumn{5}{|c|}{ Sugar beet } & \multicolumn{5}{|c|}{ Sugarcane } & \multirow{2}{*}{$\begin{array}{l}\text { Difference } \\
\text { (Rs) }\end{array}$} \\
\hline & $\begin{array}{c}\text { Beet } \\
\text { yield } \\
\text { (t/ha) }\end{array}$ & $\begin{array}{c}\text { Beet } \\
\text { rate } \\
\text { (Rs/ton) }\end{array}$ & $\begin{array}{c}\text { Gross } \\
\text { income } \\
(\mathbf{R s})\end{array}$ & $\begin{array}{c}\text { Total } \\
\text { inputs } \\
\text { (Rs) }\end{array}$ & $\begin{array}{c}\text { Net } \\
\text { income } \\
(\mathbf{R s})\end{array}$ & $\begin{array}{l}\text { Cane } \\
\text { yield } \\
\text { (t/ha) }\end{array}$ & $\begin{array}{c}\text { Cane } \\
\text { rate } \\
\text { (Rs/ton) }\end{array}$ & $\begin{array}{c}\text { Gross } \\
\text { income } \\
\text { Rs }\end{array}$ & $\begin{array}{c}\text { Total } \\
\text { inputs } \\
\text { (Rs) }\end{array}$ & $\begin{array}{c}\text { Net } \\
\text { income } \\
\text { Rs }\end{array}$ & \\
\hline Antek & 53.05 & 2375 & 125994 & 35850 & 90144 & 96 & 2075 & 199200 & 61650 & 137550 & 47406 \\
\hline California & 55.76 & 2375 & 132430 & 35850 & 96580 & 96 & 2075 & 199200 & 61650 & 137550 & 40970 \\
\hline Ernestina & 53.29 & 2375 & 126564 & 35850 & 90714 & 96 & 2075 & 199200 & 61650 & 137550 & 46836 \\
\hline Esteban & 46.17 & 2375 & 109654 & 35850 & 73804 & 96 & 2075 & 199200 & 61650 & 137550 & 63746 \\
\hline Sandrina & 60.63 & 2375 & 143996 & 35850 & 108146 & 96 & 2075 & 199200 & 61650 & 137550 & 29404 \\
\hline SD-12970 & 64.03 & 2375 & 152071 & 35850 & 116221 & 96 & 2075 & 199200 & 61650 & 137550 & 21329 \\
\hline SD PAK 03/06 & 55.11 & 2375 & 130886 & 35850 & 95036 & 96 & 2075 & 199200 & 61650 & 137550 & 42514 \\
\hline SD PAK 04/06 & 45.60 & 2375 & 108300 & 35850 & 72450 & 96 & 2075 & 199200 & 61650 & 137550 & 65100 \\
\hline SD PAK 07/07 & 58.04 & 2375 & 137845 & 35850 & 101995 & 96 & 2075 & 199200 & 61650 & 137550 & 35555 \\
\hline SD PAK 09/07 & 62.53 & 2375 & 148509 & 35850 & 112659 & 96 & 2075 & 199200 & 61650 & 137550 & 24891 \\
\hline Mean & 55.42 & 2375 & 131625 & 35850 & 95775 & 96 & 2075 & 199200 & 61650 & 137550 & 41775 \\
\hline
\end{tabular}




\section{REFERENCES}

Abo-Shady, Kh.A., Samia, M.M. Hilal, E.El.M. El-Sheref and M.F.M Ibrahim. 2010. Yield and quality of sugar beet crop as affected by irrigation interval, cultivars and potassium fertilization in north delta. J. Agric. Res. Kafer El-Sheikh Univ. 36 (4): 361-376.

Analytical Software. 2005. Statistix 8.1 User's manual Tallahassee, FL.

Annual report. 2010-11. Pakistan Sugar Mills Association, Sindh Zone (PSMA-SZ). P-20.

Ebrahimian H. R., S. Y. Sadegheian, M.R. Jahadakbar and Z. Abbasi. 2009. Study of daptability and stability of sugar beet monogerm cultivars in different locations of Iran. J. Sugar beet. 24 (2): 1-13 (in Farsi).

Hoffmann, C.M., T. Huijbregts, N. Van Swaaij and R. Jansen. 2009. Impact of different environments in Europe on yield and quality of sugar beet genotypes. Eur. J. Agron. 30: 7-26.

Jaggard K, A. Dewar and J. Pidgeon. 1998. The relative effects of drought stress and virus yellow on the yield of sugar beet in the UK, 1980-1995. J. Agric. Sci. 103 (2): 337-343.

Kaloi, G.M., A.H. Mari, M. Zubair, R.N. Panhwar, N. Bughio, S. Junejo, G.S. Unar, and M.A. Bhutto. 2014. Performance of exotic sugar beet varieties under agro-climatic conditions of lower Sindh. J. Anim. Plant Sci. 24(4): 1135-1140.

Kapur, M. L. and R. S. Kanwar. 1990. Phosphorus Fertilization in Subtrop ical India. J. Sugar beet Res. Vol. 27 (1 \& 2): 11-19.

Khan, D., I. Khan, P. Khan and G. Rehman. 2004. Sugar beet cultivation in the southern parts of NWFP. Pakistan Sugar J. 19: 19-24.

Marlander, B., C. Hoffmann, H.J. Koch, E. Ladewig, R. Merkes, J. Petersen and N. Stockfisch. 2003. Environmental situation and yield performance of the sugar beet crop in Germany: heading for sustainable development. J. Agron. Crop Sci. 189: 201-226.

Memon, Y. M., I. Khan and R. N. Panhwar. 2004. Adoptability performance of some exotic sugar beet varieties under agro-climatic conditions of Thatta. Pakistan Sugar J. 19 (6): 42-46.

Monreal, J.A., E.T. Jimenez, E. Remesal, R. Morillo-Velarede and S. Garcia-Maurino. 2006. Proline content of sugar beet storage roots: response to water deficit and nitrogen fertilization at field conditions. Envir. and Expt. Botany. Vol 60 (2): 257-267.

Oad, F.C., A. H. Ansari, B.K. Solangi, M.U. Usmani khaili, G.N. Sohu and N.L. Oad. 2001. Performance evaluation of exotic sugar beet under selected agro-alimatic conditions of Sindh province. Int. J. Agri. Biol., Vol.3 (4): 472-474.

Oad, F.C., M.U.Usmanikhail, U.A.Buriro and M. H. Siddiqui. 2007. Plant population studies of various promising sugar beet cultivars. Pakistan Sugar J. 19(6):15-19. 
Pidgeon J, A. Werker, K. Jaggard, G. Richter, D. Lister and P. Jonse. 2001. Climatic impact on the productivity of sugar beet (Beta vulgaris L.) in Europe 1961-1995. Agric. For. Meteorol. 109 (2): 27-37.

Richter, G.M., K.W. Jaggard R.A.C. Mitchell. 2001. Modeling radiation interception and radiation use efficiency for sugar beet under variable climatic stress. Agric. For. Meteorol. 109(2): 13-25.

Tunio, G.S., H.I. Majeedano, Y.J. Minhas and M.U. Usmanikhail. 2004. Performance of different sugar beet cultivars under Hyderabad conditions. Pak. Sugar J. 19 (1): 22-26.

Wandke, G., D. Bollmann, K. Mahmood, K. Kifah and K. Mahmood. 2007. Sugar beet a Supplement to Sugarcane for sugar production in Pakistan Report on the Fact Finding Mission. P: 20-21. 